\title{
HUBUNGAN ANTARA KONSEP DIRI AKADEMIK DENGAN PERILAKU MENYONTEK
}

\section{THE RELATIONSHIP BETWEEN THE ACADEMIC SELF-CONCEPT TO CHEATING BEHAVIOR}

\author{
Andi Baso Tenriumputakbir ${ }^{1}$, Aspin ${ }^{2}$, Eva Herik ${ }^{3}$ \\ Program Studi Psikologi \\ Fakultas Keguruan dan Ilmu Pendidikan, Universitas Halu Oleo \\ andibasotenriumputakbir28@gmail.com ${ }^{1}$, Aspin.psi@gmail.com ${ }^{2}$, \\ herick.eva@gmail.com ${ }^{3}$
}

\begin{abstract}
ABSTRAK: Penelitian ini bertujuan untuk mengetahui hubungan antara konsep diri akademik dengan perilaku menyontek pada siswa kelas VIII SMPN 10 Kendari. Masalah dalam penelitian ini adalah siswa SMPN 10 Kendari pernah melakukan perilaku menyontek pada saat ulangan. Subjek penelitian ini berjumlah 102 orang dari kelas VIII. Teknik pengambilan sampel menggunakan purposive sampling. Pengumpulan data menggunakan skala konsep diri akademik dari Khafiya yang dimodifikasi oleh peneliti dan juga skala perilaku menyontek dari Sah yang dimodifikasi oleh peneliti. Metode analisis data mengunakan uji korelasi Product Moment Pearson. Hasil analisis data didapatkan nilai signifikansi korelasi sebesar 0,000 dan korelasi pearsonsebesar -0,420. Sehingga dapat disimpulkan bahwa terdapat hubungan negatif yang signifikan antara konsep diri akademik dengan perilaku menyontek pada siswa kelas VIII SMPN 10 Kendari.
\end{abstract}

Kata Kunci :konsep diri akademik, perilaku menyontek

\begin{abstract}
ABSTRACK: This study aims to determine the relationship between academic self-concept andcheating behavior in eighth grade students of SMPN 10 Kendari. The subjects of this study were102 people from class VIII. The sampling technique uses purposive sampling. Data collection uses an academic self-concept scale from Khafiya (2018) which modified by researchers and also the scale of cheating behavior from Sah (2014) is modified by researchers. Data analysis method uses Pearson Product Moment correlation test. Results Analysis of the data obtained a significance value of correlation of 0,000 and Pearson correlation of -0.420. So it can be concluded that there is a significant negative relationship betweenacademic self-concept with cheating behavior in class VIII students of SMPN 10 Kendari.
\end{abstract}

Keywords: academic self concept, cheating behavior 


\section{Pendahuluan}

Pendidikan merupakan bagian terpenting dalam aspek kehidupan sebagai bekal dalam rangka membentuk manusia yang cerdas dan berkualitas sehingga diharapkan dapat menciptakan peserta didik yang berdaya saing tinggi untuk menghadapi persaingan diera globalisasi dewasa ini. Tertulis dalam Undang-undang Sistem Pendidikan Nasional Republik Indonesia No. 20 Tahun 2003 Pasal 1 Ayat 1 bahwa yang dimaksud dengan pendidikan adalah usaha sadar dan terencana untuk mewujudkan suasana belajar dan proses pembelajaran agar peserta didik secara aktif mengembangkan potensi dirinya, (Depdiknas 2003).

Purwanto (2011), menyatakan bahwa belajar adalah proses dalam diri individu yang berinteraksi dengan lingkungan untuk mendapatkan perubahan dalam perilaku.Sinhdunata(Poniati, 2015), memaparkan tujuan dari usaha belajar adalah mencapai prestasi belajar, untuk memperoleh prestasi yang memuaskan di perlukan usaha positif dan negatif. Usaha yang positif dengan meningkatkan motivasi belajar, sedangkan usaha yang negatif adalah dengan menyontek.

Menyontek merupakan salah satu bentuk perilaku ketidakjujuran akademik (academic dishonesty) yang dapat ditemukan di sekolah-sekolah baik tingkat dasar, menengah, maupun perguruan tinggi,(Pujiatni \& Lestari 2010). Sejalan dengan penelitian Dieghton (Kushartanti, 2009), perilaku menyontek merupakan upayayang dilakukan oleh seseorang untuk mendapatkan keberhasilan dengan cara-cara yang tidak jujur. Davis, Patrick, \& Tricia(2009), juga memaparkan bahwa menyontek bukanlah suatu usaha yang benar untuk mencapai keberhasilan dalam tes, dimana menyontek sama halnya dengan tindakan menipu diri, menipu teman, dan menipu orang tua.

Berdasarkan hasil pembagian angket kepada siswa kelas VIII SMP Negeri 10 Kendari yang berjumlah 173 siswa, ditemukan bahwa 102 siswa pernah melakukan perilaku menyontek, sedangkan 71 lainnya tidak pernah melakukan perilaku menyontek. Alasan siswa melakukan perilaku menyontek yaitu tidak mengetahui jawaban, tidak belajar dan ingin mendapatkan nilai yang baik. Dari 102 siswa 77 diantaranya menyontek sejak SD, 14 diantaranya menyontek sejak SMP dan 11 lainnya ketika ulangan dan pelajaran matematika. Siswa melakukan perilaku menyontek 102 diantaranya tidak percaya diri dan ketika siswa menyontek ada perasaan takut, biasa saja dan malumalu. Dari data di atas dapat disimpulkan bahwa 102 siswa di SMPN 10 Kendari masih menunjukkan perilaku menyontek.

Sejalan dengan temuan di lapangan, Fadhilah, Rusman \& Sudirman(2017), memaparkan bahwa perilaku menyontek pada siswa disebabkan karena keinginan siswa untuk memperoleh nilai yang baik tanpa usaha yang sebanding dengan nilai tersebut. Siswa tersebut kurang menghargai proses pembelajaran dan siswa cenderung menghalalkan cara apapun untuk mencapai tujuan yang diinginkan.

Santoso (2016), memaparkan bahwa siswa-siswa yang menyontek memiliki gejala-gejala perilaku melakukan penundaan dalam mengerjakan tugas, meniru pekerjaan teman saat mendapatkan tugas atau pada waktu ujian, malas mencatat atau meremehkan pelajaran dari guru, jarang mempersiapkan ujian atau malas belajar ketika akan menghadapi ujian. Gejala perilaku siswa tersebut menyebabkan beberapa perilaku siswa seperti meminta jawaban pada teman saat mengerjakan tugas atau ujian, menulis di sobekan kertas yang disembunyikan di lipatan baju, bisa juga dengan melihat buku pedoman atau buku catatan sewaktu ujian,fotocopy buku catatan yang diperkecil.

Perilaku menyontek yang dilakukan oleh siswa dapat disebabkan oleh beberapa faktor diantaranyaself efficacy (Shara,2010). 
Kepercayaan diri (Kushartanti, 2009), dan juga konsep diri akademik (Samiroh \& Muslimin, 2015). Namun pada penelitian ini lebih berfokus pada konsep diri akademik siswa mengenai perilaku menyontek yang mereka lakukan.

Konsep diri akademik adalah evaluasi individu mengenai diri sendiri, penilaian atau penaksiran mengenai diri sendiri oleh individu yang bersangkutan, (Chaplin, 2000). Konsep diri akademik yang baik sangat penting bagi siswa untuk membangun kepercayaan diri pada saat melaksanakan tugas-tugasnya, baik yang bersifat akademik maupun non akademik. Apabila dalam diri siswa tidak tumbuh konsep diri yang baik, hal itu akan sangat menghambat siswa dalam pendidikannya, terutama dalam proses perolehan ilmu yang akan didapatkan. Siswa akan cenderung melakukan hal yang tidak terpuji untuk mencapai keberhasilannya, salah satunya yaitu dengan menyontek, (Poniati, 2015).

Terkait keberhasilan dalam akademik tidak lepas dari orang tua dan masyarakat, dimana sebagian besar mereka memandang bahwa prestasi diperoleh dari nilai yang tinggi. Adanya hal tersebut menyebabkan siswa merasa tertekan, sehingga siswa lebih cenderung berorientasi untuk mendapatkan nilai yang tinggi dengan cara yang tidak wajar dibandingkan dengan memperhatikan sikap dalam proses belajar. Hal tersebut sejalan dengan yang dikemukakan oleh Istamala (2012), dimana ia berpendapat bahwa prestasi akademik tidak hanya ditentukan oleh kecerdasan tetapi juga kepribadian dan konsep diri akademik. Siswa dengan konsep diri akademik positif akan merasa yakin terhadap kemampuannya, sedangkan siswa dengan konsep diri akademik negatif cenderung pesimis.

Burns (1993), mengemukakan bahwa konsep diri akademik dan prestasi akademik berkaitan secara erat. Konsep diri akademik yang positif dapat membantu seseorang untuk meningkatkan kepercayaan terhadap dirinya sehingga dapat memotivasi seseorang untuk dapat menjadi lebih baik lagi. Konsep diri akademik merupakan hal penting dalam membentuk tingkah laku, termasuk tingkah laku menyontek. Pendidik semakin menyadari dampak konsep diri akademik terhadap tingkah laku anak dalam kelas dan terhadap prestasinya. Bastaman (2005) juga menyatakan bahwa citra diri atau konsep diri yang positif akan mewarnai pola sikap, cara pikir, corak penghayatan, dan ragam perbuatan yang positif pula, demikian juga sebaliknya.

Paparan di atas menunjukkan bahwa konsep diri akademik negatif terhadap siswa dalam hal akademik akan mengarah pada pembentukan perilaku menyontek, dimana hal tersebut merupakan permasalahan yang menarik dan relevan untuk dikaji lebih lanjut karena memiliki dampak yang luas terhadap sikap pribadi siswa. Untuk itulah penelitian ini diadakan, yaitu untuk menguji ada atau tidaknya hubungan antara konsep diri akademik dengan perilaku menyontek, sehingga peneliti menganggap perlu meneliti tentang "Hubungan antara Konsep Diri Akademik dengan Perilaku Menyontek pada Siswa Kelas VIII SMP Negeri 10 Kendari. Tujuan dari penelitian ini adalah apakah ada hubungan antara konsep diri akademik dengan perilaku menyontek pada siswa kelas VIII SMP Negeri 10 Kendari. Serta manfaat penelitian secara teoritis diharapkan dapat memberikan sumbangan pemikiran ilmiah bagi pengembangan ilmu psikologi, khususnya pada bidang psikologi pendidikan dan psikologi perkembangan terkait dengan peranan konsep diri akademik pada perilaku menyontek. Sedangkan secara praktis diharapkan dapat bermanfaat dalam memberikan informasi kepada pelaksana pendidikan (guru, siswa, orang tua siswa, pengurus sekolah) dan juga kepada siapa saja yang selalu memprhatikan perkembangan pendidikan tentang perilaku siswa dalam menyontek dan hal-hal apa saja yang dapat 
mempengaruhinya serta hubungan antara konsep diri akademik dengan perilaku menyontek pada siswa.

\section{Metode Penelitian}

Penelitian ini dilakukan pada siswa kelas VIII SMPN 10 Kendari yang berjumlah 173 siswa. Sampel penelitian ini berjumlah 102 siswa. Jenis penelitian ini ialah jenis penelitian kuantitatif dengan menggunakan desain penelitian korelasional. Teknik pengambilan sampel menggunakan purposive sampling. Metode pengumpulan data menggunakan skala konsep diri oleh Khafiya (2018) dan skala perilaku menyotek yang disusun oleh Sah (2014). Konsep diri akademik adalah pandangan dan perasaan seseorang terhadap dirinya sendiri yang yang berhubungan dengan bidang akademik. Dalam menilai dirinya, seseorang ada yang menilai positif dan ada yang menilai negatif. Maksudnya individu tersebut ada yang mempunyai konsep diri akademik yang positif dan ada yang mempunyai konsep diri yang negatif. Perilaku menyontek adalah tindakan seseorang secara sengaja untuk melakukan suatu perbuatan yang curang, tidak jujur dan tidak legal untuk mendapatkan jawaban pada saat tes dan memperoleh nilai secara tidak sah dengan memanfaatkan informasi dari luar. dalam hal ini individu menggunakan berbagai cara untuk mendapatkan hasil yang diinginkan tanpa bersusah payah belajar maupun memahami materi.

Data penelitian dianalisis dengan menggunakan teknik inferensial peneliti menggunakan teknik analisis data korelasi Product Moment Pearsonuntuk menguji hipotesis dalam penelitian.

\section{Hasil Penelitian dan Pembahasan Hasil Penelitian}

Hasil uji normalitas menjelaskan bahwa kedua data variabel penelitian terdistribusi normal.
Tabel 1 Uji Normalitas

Variabel $N$ Kolmogrov- Sig Ket Smirnov

\begin{tabular}{lllll}
\hline Konsep & & & & \\
Diri & & & & \\
Akademik & 102 & 0,061 & $0,200 \quad$ Normal \\
dengan & & & & \\
Perilaku & & & & \\
Menyontek & & & & \\
\hline
\end{tabular}

Berdasarkan hasil uji normalitas data dengan menggunakan teknik OneSample Kolmogrov Smirnov pada SPSS 25.0 menunjukkan nilai signifikansi sebesar 0,200. Nilai ini lebih besar dari 0,05 , hal tersebut menunjukkan bahwa data variabel konsep diri akademik dan perilaku menyontek terdistribusi normal.

\section{Uji Linearitas}

Hasil Uji Linearitas ditemukan bahwa hubungan antara variabel konsep diri dan perilaku menyontek memiliki hubungan linear.

Tabel 2 Uji Linearitas

\begin{tabular}{llll}
\hline Variabel & $\begin{array}{l}\text { Sig. Deviation } \\
\text { Linearity }\end{array}$ & \\
\hline Konsep & Diri & 0.208 & \\
Akademik & 0.208 & \\
Perilaku & & \\
Menyontek & & \\
\hline
\end{tabular}

Berdasarkan hasil uji linearitas data dengan menggunakan tes for linearity menunjukkan nilai signifikansi deviation from linearity sebesar 0,208. Nilai ini lebih besar dari 0,05 , hal tersebut menunjukkan bahwa data variabel konsep diri akademik dan variabel perilaku menyontek dinyatakan memiliki hubungan.

Uji hipotesis dilakukan dengan menggunakan teknik korelasi Pearson Product Moment dengan menggunakan bantuan Program SPSS versi 25.0 for windows. Hasil analisis datadiperoleh angka koefisien korelasi sebesar $-0,420$, 
dengan nilai signifikansi sebesar 0.000 , maka ada hubungan antara konsep diri akademik dengan perilaku menyontek pada siswa kelas VIII SMPN 10 Kendari.

\begin{tabular}{llll}
\multicolumn{4}{c}{ Tabel 3 Uji Hipotesis } \\
\cline { 1 - 3 } Variabel & $N$ & $\begin{array}{l}\text { Person } \\
\text { Correlatio } \\
n\end{array}$ & Sig. \\
\cline { 1 - 3 } $\begin{array}{l}\text { Konsep Diri } \\
\text { Akademik }\end{array}$ & $\begin{array}{l}n \\
\text { Akn }\end{array}$ & $-0,420^{* *}$ & 0.000 \\
\cline { 1 - 3 } $\begin{array}{l}\text { Perilaku } \\
\text { Menyontek }\end{array}$ & 10 & $-0,420^{* *}$ & 0.000 \\
\hline
\end{tabular}

\section{Pembahasan}

Salah satu faktor yang mempengaruhi konsep diri pada siswa adalah perilaku menyontek, Friyatmi (Ulfa 2017). Siswa kelas VIII SMPN 10 Kendari masih banyak ditemukan perilaku menyontek seperti tugas yang diberikan pada siswa pada saat pembelajaran, siswa masih kurang mampu dalam mengerjakan tugas secara mandiri, dan siswa masih menyontek pada saat ulangan semester. Hal ini sejalan dengan salah satu faktor yang dikemukakan oleh Jahja (Sah, 2014), yaitu faktor-faktor yang mempengaruhi perilaku menyontek salah satunya keinginan untuk mendapatkan nilai yang tinggi.

Siswa yang memiliki konsep diri akademiknegatif cenderung melakukan perilaku menyontek karena dipengaruhi oleh status sosial, karena status sosial memiliki hubungan yang tinggi dengan prestasi belajar individu. Hal ini sejalan dengan salah satu faktor yang dikemukakan Hattie (Khafiya, 2018) yaitu faktor-faktor yang mempengaruhi konsep diri akademik salah satunya status sosial yang meliputi pekerjaan ayah, pendidikan orang tua dan kemampuan untuk melanjutkan pendidikan.

Atmasari (Khotimah dkk, 2016),menyatakan bahwa konsep diri akademik adalah gambaran individu terhadap kemampuan akademiknya, yang meliputi kemampuan dalam mengikuti kegiatan pembelajaran, kemampuan meraih prestasi di bidang akademik, serta aktivitas di sekolah atau di kelas yang berkaitan dengan persepsi, pikiran, perasaan dan penilaian seseorang terhadap kemampuan akademiknya.Adapun aspekaspek konsep diri akademik antara lain classroom self concept (konsep diri kelas), ability self concept (konsep diri akademik) dan achievement self concept (konsep diri prestasi). Siswa yang tidak mampu dalam menyelesaikan tugas akademik dengan baik, akan berperilaku negatif seperti menyontek. Sebelum menghadapi tes siswa sudah merasa tidak mampu untuk mengerjakan soal tes dengan baik dan benar, sehingga siswa akan mencari cara yang instan agar bisa menyelesaikan soal tes yaitu dengan menyontek, (Sugiyo, dalam Ulfa, 2017).

Bower (Nurmayasari \& Murusdi 2015), mendefinisikan menyontek adalah perbuatan yang menggunakan cara-cara yang tidak sah untuk tujuan yang sah dan terhormat yaitu mendapatkan keberhasilan akademik untuk menghindari kegagalan akademik.Bentuk-bentuk perilakunya antara lain menggunakan catatan dalam ujian, mencari jawaban melalui teman saat ujian, bekerjasama dengan teman dalam ujian dan bekerjasama dalam menyelesaikan tugas.

Hasil penelitian menunjukkan ada hubungan antara kedua variabel dengan koefisien korelasi bertanda negatif yang diperoleh angka koefisien sebesar - 0,420 , yang berarti semakin tinggi konsep diri akademik maka semakin rendah perilaku menyontek, sebaliknya semakin rendah konsep diri akademik maka semakin tinggi perilaku menyontek pada siswa kelas VIII SMPN 10 Kendari. Dari hasil tersebut maka hipotesis penelitian dapat diterima yakni ada hubungan negatif signifikan antara konsep diri akademik dengan perilaku menyontek pada siswa kelas VIII SMPN 10 Kendari.

Salah satu kendala yang peneliti hadapi yaitu adanya keterabatasan waktu yang diberikan oleh pihak sekolah yang mengadakan ulangan semester ganjil tahun 
2019. Sehingga untuk peneliti berikutnya disarankan tidak melakukan penelitian di akhir semester.

Penelitian ini sejalan dengan penelitian terdahulu yang dilakukan oleh Setyani (2007), menunjukkan adanya hubungan negati $\mathrm{f}$ dan sangat signifikan antara konsep diri dengan intensi menyontek yang ditunjukkan oleh angka korelasi $r x y=-0,464$ dengan $\mathrm{p}=0,000$ $(p<0,05)$, yang $b$ erarti terdapat hubungan negatif yang sangat signifikan antara konsep diri dengan intensi menyontek pada siswa SMA Negeri 2 Semarang. Selain itu, penelitian ini sejalan pula dengan penelitian yang dilakukan oleh Samiroh \&Muslimin (2015), melakukan penelitian tentang "Hubungan Antara Konsep Diri Akademik dengan Perilaku Menyontek pada Siswa-siswi MAS Simbangkulon Buaran Pekalongan". Hasil penelitian menunjukkan nilai rxy $=-0.522$, yang artinya ada hubungan yang negatif yang signifikan antara konsep diri akademik dengan perilaku menyontek.

\section{Kesimpulan dan Saran Kesimpulan}

Berdasarkan hasil penelitian yang telah dilakukan, dapat disimpulkan bahwa hipotesis dalam penelitian ini diterima, dengan nilai signifikansi sebesar 0,000 . Nilai tersebut lebih kecil dari 0,05 artinya terdapat hubungan yang signifikan antara konsep diri akademik dengan perilaku menyontek pada siswa kelas VIII SMPN 10 Kendari. Lebih lanjut peneliti menemukan hubungan positif antara konsep diri akademik dengan perilaku menyontek dengan nilai koefisien korelasi sebesar $-0,420$, yang berarti semakin tinggi konsep diri akademik maka semakin rendah perilaku menyontek, sebaliknya semakin rendah konsep diri akademik maka semakin tinggi perilaku menyontek.

\section{Saran}

Siswa diharapkanlebih mengenal diri dan potensi-potensi yang dimiliki serta mampu mengembangkannya, baik dalam bidang akademik maupun non akademiksehingga tidak hanya berorientasi pada nilai pelajaran sehingga dapat meminimalisir perilaku menyontek.

Sedangkan orang tua hendaknya senantiasa menciptakan lingkungan psikologis yang mampu mempertahankan terwujudnya konsep diri akademik positif dengan memberi penghargaan terhadap prestasi yang sudah diraih anak. Orang tua diharapkan tidak memberi target nilai yang harus dicapai oleh anak karena dapat membuat anak tertekan, dan tidak menghargai anak hanya dari nilai rapor yang diperoleh tapi juga dari proses belajar anak. Orang tua sebaiknya memberi perhatian dan mengontrol proses belajaranak, memberi pengertian dan motivasi pada anak tentang pentingnya proses belajar sehingga anak tidak berorientasi pada hasil atau nilai sehingga dapat meminimalisir perilaku menyontek.

Sekolah juga diharapkan dapat menciptakan suasana yang mendukung tumbuhnya konsep diri akademik yang positif sehingga dapat meminimalisir perilaku menyontek siswa. Membantu siswa mengenali kekuatannya dan mengembangkan potensi diri, memberi penghargaan terhadap prestasi yang diraih siswa dalam bidang akademik maupun non akademik, dapat membantu terwujudnya konsep diri akademik positif. Berkaitan dengan pelaksanaan ujian, sekolah diharapkan membuat sistem ujian dan menggunakan bentuk soal yang meminimalisir perilaku menyontek.

\section{Daftar Pustaka}

\section{Bastaman, H. D. (2005). Integrasi Psikologi Dengan Islam. Yogyakarta: Yayasan Insan Kamil.}

Burns, R. B. (1993). Konsep Diri: Teori, Pengukuran, Perkembangan, dan Perilaku. (Alih Bahasa: Edy). Jakarta: Arcan. 
Chaplin, J. P. (2000). Kamus Lengkap Psikologi. Jakarta: Rajawali.

Davis, S.F., Patrick, F.D., \& Tricia, B.G. (2009). Cheating In School What We Know and What We Can Do. Singapore: Wiley-Blackwell.

Depdiknas.2003. Undang-undang RI No.20 tahun 2003. Tentang sistem pendidikannasional.http://kelembaga an.ristedikti.go.id2016/08UU_no_20 _2003.

Fadhilah, N, Rusman, Sudirman Z. (2017). Hubungan Konsep Diri Dengan Intensi Mencontek Siswa Sekolah Dasar Negeri 16 Banda Aceh. Jurnal Ilmiah Pendidikan Guru Sekolah Dasar FKIP Unsyiah, 2 (4), 88-97.

Istamala, M. S. (2012). Hubungan Konsep Diri Dengan Intensi Mencontek Siswa Kelas XII SMA

Negeri 1 Plaosan Kabupaten Magetan. Skripsi. Fakultas Psikologi Universitas Islam Negeri (UIN) Maulana Malik Ibrahim Malang.

Khafiya, H, N. (2018). Konsep Diri Akademik Pada Siswa MTS (Studi Pada Siswa Yang Berasal Dari SD Umum). Skripsi. Fakultas Psikologi Universitas Muhammadiyah Malang.

Khotimah, R, H. Carolina, L. Radjah. Dany, M. Handarini. (2016). Hubungan Antara Konsep Diri Akademik, Efikasi Diri Akademik, Harga Diri dan Prokrastinasi Akademik Pada Siswa SMP Negeri Di Kota Malang. Jurnal Kajian Bimbingan dan Konseling 1(2), 6067.

Kushartanti, A. (2009). Perilaku Mencontek Ditinjau dari Kepercayaan Diri. Jurnal Indigenous Ilmiah Berkala Psikologi 11 (2), 3846.
Nurmayasari, K. \& Murusdi, H. (2015). Hubungan Antara Berpikir Positif Dan Perilaku Menyontek Pada Siswa Kelas X SMK Koperasi Yogyakarta. Jurnal Fakultas Psikologi, 3 (1), 815.

Poniati, H. (2015). Hubungan Antara Konsep Diri Dengan Perilaku Menyontek Pada Siswa SMKK Santo Yusuf 2 Wonodadi Tahun Ajaran 2014/2015. Artikel Skripsi. Kediri: Universitas Nusantara PGRI Kediri.

Pujiatni, K \& Lestari, S. (2010). Studi Kualitatif Menyontek Pada Mahasiswa. Jurnal Penelitian Humaniora, 11 (2), 103-110.

Purwanto, (2011). Evaluasi Hasil Belajar, Yogyakarta: Pustaka Pelajar. http://repository.unpas.ac.id/12953/5/ BAB\%2011\%20PDF.pdf. (diakses 19 Agustus 2019).

Sah, M,M. (2014). Hubungan Locus Of Control Dan Ketakutan Akan Kegagalan Dengan Perilaku Menyontek Pada Siswa. Tesis. Program Pasca Sarjana Uviversitas Muhammadiyah Surakarta.

Samiroh \& Muslimin, Z, I. (2015). Hubungan Antara Konsep Diri Akademik Dan Perilaku Menyontek Pada Siswa-Siswi Mas Simbangkulon Buaran Pekalongan. Jurnal Psikologi Islami, 1 (2), 67-77.

Santoso, P. (2016). Hubungan Antara Konsep Diri dengan Perilaku Menyontek Siswa Kelas VIII SMP N 10 Yogyakarta Tahun Ajaran 2015/2016. Skiripsi. Fakultas Keguruan dan Ilmu Pendidikan Universitas PGRI Yogyakarta.

Setyani, U. (2007). Hubungan Antara Konsep Diri dengan Intensi Menyontek pada Siswa SMA Negeri 
2 Semarang. Skripsi. Fakultas Kedokteran Universitas Diponegoro.

Shara, S. (2010). Hubungan Self-Efficacy dan Perilaku Menyontek (CHEATING) Pada Mahasiswa Fakultas Psikologi Universitas X. Jurnal Ilmiah Psikologi, 9 (1), 42-29.

Ulfa, M. (2017). Hubungan Antara Konsep Diri Dan Efikasi Dengan Perilaku Menyontek Pada Siswa Kelas VIII MTS Se-Kecamatan Welahan Kabupaten Jepara Tahun Pelajaran 2016/2017. Skripsi. Fakultas Ilmu Pendidikan Universitas Negeri Semarang. 